\title{
Evaluation of Some School Applications in Turkish National Education according to Students' Viewpoints
}

\author{
Erol Sözen ${ }^{1}$, Mücahit Coşkun ${ }^{2}$ \\ ${ }^{1}$ Düzce University, Faculty of Education, Basic Education Department, Düzce, Turkey \\ ${ }^{2}$ Karabük University, Faculty of Letters, Geography Department, Karabük, Turkey \\ Correspondence: Mücahit Coşkun, Karabük University, Faculty of Letters, Geography Department, Karabük, Turkey.
}

Received: January 3, 2017

doi:10.11114/jets.v5i3.2243
Online Published: February 23, 2017

URL: https://doi.org/10.11114/jets.v5i3.2243

\begin{abstract}
The purpose of this study is to evaluate students' perspectives according to various variables about use of smart boards and tablet computers in class rooms, academic performance tasks, distribution of course books, and changes made in exam grading regulation at high schools which came into effect as of academic year 2013-2014 under Faith Project. Formulation and application of measurement techniques and data collection were performed with high school students in Düzce province. A correlational comparative survey method was applied with quantitative research approach in this study. Statistical Package Program SPSS 20.0 was used in data analysis. Descriptive statistics analysis was performed to evaluate frequency values, percentages and arithmetic average values, while, One-Way Variance Analysis (ANOVA) and $\boldsymbol{t}$-test were used for unrelated sampling. A sample of 606 students was selected from various high schools in Düzce during academic year 2015-2016. Students' viewpoints on the categories defined in measurement scale were determined generally as "I am indecisive" or "I agree".

Resultantly, no significant differences were found in students' opinions according to gender and residential area variables. On the other hand, significant differences were detected in students' perspectives on use of smart boards, performance tasks and course books distribution according to the school type variable. Use of smart board was found to be considered more positively in Anatolian high schools, while, performance task and course book distribution were considered more positively in vocational schools. Moreover, it was also found that students' viewpoints on use of tablet computers and distribution of course books showed significant differences according to the variable of class size. Students' viewpoints on use of smart board and tablet computers, performance task, and distribution of course books were found to be viewed more positively in classes with strength of 21-25 students.
\end{abstract}

Keywords: faith project, course book, performance task, class passing grade regulation, students' viewpoints

\section{Introduction}

One of the most frequently emphasized issues considered by societies in the continuously changing and developing world is the quality of trained human force. Societies can only develop with increase in the number of the humans who follow any innovation and who are experts in their fields. For this reason, each state has to review its share of the budget spent on education in its future plans and work to provide its citizens with a more efficient and productive educational system. Chinese poet Chuang Tzu explained the importance of education in 650 B.C. as follows: "If your plan is for one-year plant rice. If your plan is for ten years plant trees. If your plan is for one hundred years educate children". If you plant a seed once, you receive the yield once; if you plant a tree once, you receive ten-fold yield; and this yield becomes hundred-fold if you educate the nation." Chinese poet stated this famous statement nearly 2700 years ago, and since then, the importance of education in the social change and development of societies has continued and observed throughout history (Bordanac1; 2006). Küçükahmet (1997) stated that education started with the birth of a person and continued until death, while, some part of this education is provided at schools or at classrooms in a planned and programmed manner, which is called "formal education". According to Erden and Fidan (1988), education and teaching constitute the process of socialization. The conscious and unconscious learning of a person obtained during the interaction of the person with his/her own society as a child, young and adult is acquired during this process. For this reason, education is considered as a deliberate process of socialization. Today, schools, physical infrastructures and technological equipment have become extremely important for education activities. In recent years, significant increase in the budget allocated for education 
activities is observed in Turkey. One of the important steps taken for the development of technological infrastructure of schools is Faith Project. In addition to this, for more than ten years, the Ministry of National Education (MoNE) has distributed free course books to students. However, provision of course books is also criticized sometimes by opponents of this policy (Sözen; 2011).

Faith Project has aimed to bring a different vision to the Turkish Educational System since its inception in 2010, with the objective to provide computer-assisted teaching by rendering computers and technological devices in the classrooms until late 2013 (MoNE, Faith Project, 2011). For this purpose, the components of Faith Project have been categorized under five categories which are hardware, software, e-content, use of information technologies, and in-service training of teachers.

The hardware and infrastructure are planned to be completed within 3-year period between 2010-2013 under Faith Project while, the next 2 years are proposed for evaluation of the project and its outcomes and reflections on Turkish Educational System (Alkan et al.). In context of this objective, it was proposed to address the needs of third, second and first level education in first, second and third year of the project respectively. In framework of these objectives, some pilot projects have been started at particular schools since 2011, while, pilot projects at 3 primary schools, and 50 high schools in 17 provinces have been completed until the end of academic year 2011-2012. The test projects were applied by distributing tablet computers to the students without mentioning earlier.

The regulation number 28758, dated 07-09-2013 on passing a lesson at schools was released in Official Gazette (http://www.resmigazete.gov.tr/eskiler/2013/09/2013 0907-4.htm), also_brought important changes with it. Article 36 of this regulation organized the absenteeism right again and decreased this right to 10 days from 20 days, and the right of excused absence to 45 days from 54 days. Article 44 also renewed the passing grade as 50, which was formerly 45 . Article 45 introduced the obligation of general exams. It was made compulsory to submit at least one performance task in each branch in each semester instead of oral exam grades. As a result, important changes in grading regulation at schools with profound effect on students have been observed since 2013.

A large number of research works have been done on use of computer and interactive boards as technological products used in education. Harton-Richardson-Barreras-Rocloff-Latane (2002), Kalem-Fer (2003), Bağc1 (2013), conducted a workshop in Okan University (2012) with the title "Faith Project, the Education of the Future"; Ayvac1 et al. (2014) Dinçer et al. (2014), Ateş (2010), Küçüktepe and Baykın (2014), Ekici and Yılmaz (2013), conducted several studies on the use of technology in class rooms and Faith Project, reporting important results; Merkel, 1984; Yang, 2008; also conducted studies in this field. In addition to these, Sözen (2011), Sözen and Türksever Ö. (2013) made important criticisms on course books.

\section{Purpose of the Study}

Ministry of National Education started a project named "Faith Project" in order to revive the technological equipment of schools and to make students and teachers adopted to these new technologies. In context of this project, smart boards were installed in classrooms and tablet computers were distributed to students. Besides these accomplishments, provision of free-of-charge course books at schools, changes in exam grading system and compulsory performance tasks were also introduced as part of project scheme. The purpose of present research is to evaluate students' perspectives regarding changes in exam grading regulation that came into effect during academic year 2013-2014 under Faith Project, distribution of free course books, use of smart boards in class rooms, provision of tablet computers to students and assigning the students with performance tasks. In addition, this study also analyses the differences in students' viewpoints according to various variables including gender, residential area, school types, and class size. In accordance with this purpose, following questions constitute the statement of problem and sub-problems of the study.

\subsection{Problem Statement}

What are the viewpoints of high school students about Faith Project regarding distribution of free course books, changes in regulation on exam grading system, and inclusion of performance tasks as assessment method?

\subsection{Sub-problems}

- What are the viewpoints of high school students on use of smart boards in class rooms started as of academic year 2013-2014?

- What are the viewpoints of high school students on tablet computers distribution started as of academic year 2013-2014?

- What are the viewpoints of high school students on distribution of free course books at secondary school institutions? 
- What are the viewpoints of high school students on the changes in regulation on exam grading system at schools, which came into effect as of academic year 2013-2014?

- What are the viewpoints of high school students on assigning performance tasks, which started as of academic year 2013-2014?

- Do students' viewpoints on smart board use, distribution of tablet computers, performance task, course books distribution, and regulation on exam grading system at schools, differ according to variables like gender, residential area, school type and class size at a statistically significant level?

\section{Method}

In this part of the study, we have discussed the research framework, study population and sampling techniques, methods of data collection and analysis of the data.

\section{- The Research Framework}

This study is based on correlational comparative survey method. The survey method is performed to determine certain properties of a group by collecting data (Karasar, 1994) as it is preferred in social science studies (Borg and Gall, 1971). For this reason, quantitative research methods have preferred in this study, and a suitable scale for the study has formulated and applied to high school students. The review of relevant literature and field observations were made for formulation of proper scale. Expert opinions have also used during the preparation stage of the study. In order to determine the reliability of the scale before its final application in the research it has been tested on a small part of sample. The reliability findings are explained in detail in the part of data collection techniques.

\section{- The Study Population and Sampling}

The study population consists of the students studying at secondary school institutions in Düzce during academic year 2015-2016. A sample of 606 students has been selected randomly from various high schools in Düzce city center. The demographical data of study population are given in Tables1, 2, 3 and 4. In order to get more solid and reliable data, students were asked to fill out the questionnaire whenever and wherever they want and do any possible corrections in their responses. Since the students participated voluntarily in the study, it is assumed that the results of the study are more reliable (Kerski, 2000).

Table 1. The Distribution of the students according to their genders

\begin{tabular}{lll}
\hline Gender & $N$ & $\%$ \\
\hline Female & 354 & 58 \\
Male & 252 & 42 \\
Total & 606 & 100.0 \\
\hline
\end{tabular}

The gender distribution of the student participants is given in Table 1. Result reveals that out of 606 students, 252(42\%) are male while $354(58 \%)$ are female. The number of the female students who participated in the study is more than the males. However, the distribution of the gender is not unbalanced.

Table 2. The Distribution of the students according to their School Types

\begin{tabular}{lll}
\hline School Type & $\boldsymbol{n}$ & \% \\
\hline Anatolian High School & 336 & 55 \\
Science High School & 53 & 9 \\
Teacher Training High School & 49 & 8 \\
Vocational High School & 168 & 28 \\
Total & 606 & 100,0 \\
\hline
\end{tabular}

The distribution of the students who participated in the study according to their school types is given in Table 2. In this context, 55\% ( $n=336$ ) of the students are from Anatolian High School, 28\% ( $n=168)$ from Vocational High Schools, 9\% $(n=53)$ from Science High Schools, and 8\% (n=49) from Teacher Training High Schools. The number of the students at Anatolian High Schools was more. This situation has emerged with the restructuring of the secondary education institutions in Turkey in recent years. Since many common high schools are accepted as Anatolian High Schools, therefore, this group shows more percentage in participation.

Table 3. Distribution of the students according to their residential areas

\begin{tabular}{lcl}
\hline Residential Area & $n$ & $\%$ \\
\hline Village & 165 & 27 \\
County & 114 & 19 \\
Center & 327 & 54 \\
Total & 606 & 100,0 \\
\hline
\end{tabular}


The distribution of the students according to their residential areas is given in Table 3. Accordingly, 54\% ( $n=327)$ of the students are from urban areas while $27 \%(n=165)$ are from villages and $(n=114) 19 \%$ are from counties.

Table 4. The distribution of the students, who participated in the study, according to the population of the classes they attend to

\begin{tabular}{lll}
\hline Population of the Classes (pcs) & $n$ & $\%$ \\
\hline Between 1-25 & 81 & 13 \\
$26-30$ & 289 & 48 \\
31 and over & 236 & 39 \\
Total & 606 & 100,0 \\
\hline
\end{tabular}

The distribution of students who participated in the study according to the class size is given in Table 4. Accordingly, sizes of class were as follows; those between 26-30 were 48\% ( $n=289)$; 31 and over students were 39\% $(n=236)$; those between $1-25$ were $13 \%(n=81)$. It is found that $87 \%(n=525)$ of the students who participated in the study were studying at classes where there were 26 and more students. This situation shows that the classes are still a little over-crowded in our country.

\section{Data Collection Tool}

Table 5. The variable Load Values that were obtained as a Result of Exploratory Factor Analysis of "Evaluation of Some School Applications in Turkish National Education according to Students' Viewpoints" Scale

\begin{tabular}{|c|c|c|c|c|c|}
\hline Item & Components & & & & \\
\hline Numbers & Factor 1 & Factor 2 & Factor 3 & Factor 4 & Factor 5 \\
\hline & Tablet & Performance & Smart Board & Course Books & Regulation \\
\hline M1 & 0.861 & & & & \\
\hline M2 & 0.840 & & & & \\
\hline M3 & 0.835 & & & & \\
\hline M4 & 0.815 & & & & \\
\hline M5 & 0.808 & & & & \\
\hline M6 & 0.775 & & & & \\
\hline M7 & 0.733 & & & & \\
\hline M8 & 0.679 & & & & \\
\hline M9 & 0.464 & & & & \\
\hline M10 & & 0.863 & & & \\
\hline M11 & & 0.845 & & & \\
\hline M12 & & 0.843 & & & \\
\hline M13 & & 0.843 & & & \\
\hline M14 & & 0.826 & & & \\
\hline M15 & & 0.773 & & & \\
\hline M16 & & 0.765 & & & \\
\hline M17 & & 0.361 & & & \\
\hline M18 & & 0.358 & & & \\
\hline M19 & & & 0.769 & & \\
\hline M20 & & & 0.752 & & \\
\hline M21 & & & 0.736 & & \\
\hline M22 & & & 0.728 & & \\
\hline M23 & & & 0.728 & & \\
\hline M24 & & & 0.688 & & \\
\hline M25 & & & 0.678 & & \\
\hline M26 & & & 0.540 & & \\
\hline M27 & & & 0.502 & & \\
\hline M28 & & & & 0.796 & \\
\hline M29 & & & & 0.790 & \\
\hline M30 & & & & 0.789 & \\
\hline M31 & & & & 0.736 & \\
\hline M32 & & & & 0.733 & \\
\hline M33 & & & & 0.732 & \\
\hline M34 & & & & 0.572 & \\
\hline M35 & & & & 0.391 & \\
\hline M36 & & & & & 0.774 \\
\hline M37 & & & & & 0.740 \\
\hline M38 & & & & & 0.713 \\
\hline M39 & & & & & 0.700 \\
\hline M40 & & & & & 0.673 \\
\hline M41 & & & & & 0.664 \\
\hline M42 & & & & & 0.534 \\
\hline
\end{tabular}

Present research has used an attitude measurement scale in order to determine the viewpoints of the high school students in Düzce province on the innovations made under Faith Project, such as the changes made in exam grading system, 
performance tasks and course books distribution and analysis of these viewpoints according to specific variables. The scale used in this study has developed by the authors. The scale consisted of a total of $42 \mathrm{sub}$-variables under five main categories of variables. Besides these five categories of variables, some other demographical variables are also used. The demographical variables consisted of gender, residential area, school type and size of class. Each category of variables is divided further into sub variables. In these 5 categories of variables, tablet computers distribution category consisted of 9 sub-variables; category of performance task consisted of 9 sub-variables; category of use of smart boards consisted of 9 sub-variables; category of course books distribution consisted of 8 sub-variables; and category of changes in exam grading system consisted of 7 sub-variables. In case the KMO value in such scales is over 0.60 , it is considered suitable for factor analysis (Büyüköztürk; 2013). The KMO value of the scale was found to be 0.879 . For this reason, it is considered as suitable value for factor analysis. Variable load values of the scale are given in Table 5.

The total variance explanation rate of the 5-Factor structure is 55.7\%. According to Çokluk et al. (2010) the ideal rate in multi-factor structures is between $40 \%$ to $60 \%$. The factor load values of each factor were not very close to each other and their contribution to the total variance is more than other factors. After Varimax rotation, the variables that coincided with each other in the 5 -factor structure and that had load values lower than 0.32 were excluded. As a result of the exploratory factor analysis, these items were removed and the 5-factor structure was obtained in this way. Reliability analysis reveals that the Cronbach Alpha coefficient of the scale was calculated as 0.89, thus, making the scale more reliable. The range of the points in Likert scales is given in Table 6 below.

Table 6. The Score Range of the Items of the Questionnaire with Likert Scale

\section{Analysis of the Data}

\begin{tabular}{lll}
\hline I do not agree at all & 1 & $1.00-1.80$ \\
I do not agree & 2 & $1.81-2.60$ \\
I am indecisive & 3 & $2.61-3.40$ \\
I agree & 4 & $3.41-4.20$ \\
I totally agree & 5 & $4.21-5.00$ \\
\hline
\end{tabular}

The statistical analyses were made by using SPSS 20.0. In the analyses of the data, along with descriptive statistics, t-test and One-Way variance analysis (ANOVA) were used for unrelated samplings. Turkey test was used in comparing the groups. The significance level was found as 0.05 .

\section{Findings and Comments}

Descriptive statistics was used to find out the frequency values, percentage distributions, arithmetic averages and similar statistical values in the data based on answers given according to 5 point Likert scale. In order to find whether there was a significant difference between students' viewpoints in terms of two group variables (like gender) unrelated sampling t-test was applied. One-Way Variance Analysis (ANOVA) was used to find whether there were significant differences between the students' viewpoints in three and more group variables (like Residential Area, School Type and average class populations). In case the differences were detected, the Turkey Multiple Comparison Test was used to determine the different group. The significance level was 0.05 . The choices and points of the sentences in the scale are as follows:

Table 7. The t-test Results of the Sub-dimensions of the Some School Applications in Turkish National Education Scale

\begin{tabular}{|c|c|c|c|c|c|c|c|}
\hline Dimensions & Gender & $\mathrm{n}$ & $x$ & $S$ & $\mathrm{sd}$ & $\mathrm{t}$ & $\mathrm{p}$ \\
\hline \multirow{2}{*}{ Smart Board } & Female & 354 & 3.49 & .72 & \multirow{2}{*}{604} & \multirow{2}{*}{.28} & \multirow{2}{*}{.77} \\
\hline & Male & 252 & 3.47 & .75 & & & \\
\hline \multirow{2}{*}{ Performance Task } & Female & 354 & 3.11 & .92 & \multirow{2}{*}{604} & \multirow{2}{*}{.69} & \multirow{2}{*}{.49} \\
\hline & Male & 252 & 3.06 & 1.02 & & & \\
\hline \multirow{2}{*}{ Tablet } & Female & 354 & 3.01 & .93 & \multirow{2}{*}{604} & \multirow{2}{*}{-1.85} & \multirow{2}{*}{.06} \\
\hline & Male & 252 & 3.16 & .97 & & & \\
\hline \multirow{2}{*}{ Course book } & Female & 354 & 3.08 & .79 & & \multirow{2}{*}{-.62} & \multirow{2}{*}{.54} \\
\hline & Male & 252 & 3.12 & .80 & 604 & & \\
\hline \multirow{2}{*}{ Regulation Change } & Female & 354 & 3.28 & .87 & & \multirow{2}{*}{-.24} & \multirow{2}{*}{.80} \\
\hline & Male & 252 & 3.30 & .81 & 604 & & \\
\hline
\end{tabular}

Analysis of t-test given in table 7 shows that the students' viewpoints do not differ at a significant level on smart board use $[t(604)=.28 ; p>.05]$, performance task $[t(604)=.69 ; p>.05]$, tablet computers $[t(604)=-1.85 ; p>.05]$, course book $[t(604)=-, 62 ; p>.05]$ and on exam grading system $[t(604)=-.24 ; p>.05]$. It is also found that gender does not seem to be a significant determinant in students' viewpoints. In addition, it is also observed that average viewpoints of the students on smart board use were determined as "I agree". The students' viewpoints on performance task, tablet computers' distribution, course book distribution and on exam grading regulation were determined as "I am indecisive". 
Table 8. One Way ANOVA Result of "Some School Applications in Turkish National Education Scale Sub-Dimension" according to Residential Area

\begin{tabular}{|c|c|c|c|c|c|c|c|}
\hline Dimensions & Residential Area & $\mathrm{N}$ & $\mathrm{x}$ & $\mathrm{S}$ & sd & $\mathrm{F}$ & $\mathrm{p}$ \\
\hline \multirow{3}{*}{ Smart Board } & Village & 165 & 3.46 & .66 & 2 & \multirow{3}{*}{.42} & \multirow{3}{*}{.65} \\
\hline & County & 114 & 3.44 & .65 & 603 & & \\
\hline & Center & 327 & 3.51 & .80 & 605 & & \\
\hline \multirow{3}{*}{$\begin{array}{l}\text { Performance } \\
\text { Task }\end{array}$} & Village & 165 & 3.20 & .84 & 2 & \multirow{3}{*}{2.80} & \multirow{3}{*}{.06} \\
\hline & County & 114 & 3.18 & .89 & 603 & & \\
\hline & Center & 327 & 3.01 & 1.04 & 605 & & \\
\hline \multirow{3}{*}{ Tablet } & Village & 165 & 2.96 & .90 & 2 & \multirow{3}{*}{1.70} & \multirow{3}{*}{.18} \\
\hline & County & 114 & 3.11 & .97 & 603 & & \\
\hline & Center & 327 & 3.13 & .97 & 605 & & \\
\hline \multirow{3}{*}{ Course book } & Village & 165 & 3.11 & .74 & 2 & \multirow{3}{*}{.11} & \multirow{3}{*}{.89} \\
\hline & County & 114 & 3.12 & .72 & 603 & & \\
\hline & Center & 327 & 3.09 & .85 & 605 & & \\
\hline \multirow{3}{*}{$\begin{array}{l}\text { Regulation } \\
\text { Change }\end{array}$} & Village & 165 & 3.31 & .80 & 2 & \multirow{3}{*}{.07} & \multirow{3}{*}{.93} \\
\hline & County & 114 & 3.28 & .89 & 603 & & \\
\hline & Center & 327 & 3.29 & .85 & 605 & & \\
\hline
\end{tabular}

Keeping in view the One Way ANOVA results given in table 8, it is found that students' viewpoints on smart board use $[F(2-603)=.42 ; p>.05]$, performance task $[F(2-603)=2.80 ; p>.05]$, use of tablet computers $[F(2-603)=1.70 ; p>.05]$, course book distribution $[F(2-603)=.11 ; p>.05]$, and changes in exam grading system $[F(2-603)=.07 ; p>.05]$ do not differ at a significant level according to the residential area variable. Therefore, residential area does not seem to be a determinant variable in students' viewpoints. In addition, it is also observed that students' viewpoint on smart board application is at "I agree" level. The viewpoints of the students on performance task, tablet computers distribution, course book distribution and changes in exam grading system regulation were determined to be "I am indecisive".

Table 9. One-Way ANOVA Results of Some School Applications in Turkish National Education Scale Sub-Dimension according to School Type

\begin{tabular}{|c|c|c|c|c|c|c|c|c|}
\hline Dimensions & School Type & $\mathrm{n}$ & $\mathrm{x}$ & $\mathrm{S}$ & $\mathrm{sd}$ & $\mathrm{F}$ & $\mathrm{p}$ & Difference Turkey \\
\hline \multirow{4}{*}{ Smart Board } & Anatolian High School & 336 & 3.54 & .73 & & \multirow{4}{*}{3.11} & \multirow{4}{*}{.03} & \multirow{4}{*}{ 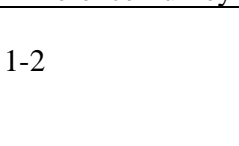 } \\
\hline & Science High School & 53 & 3.24 & .79 & 3 & & & \\
\hline & Teacher Training High School & 49 & 3.35 & .85 & 602 & & & \\
\hline & Vocational High School & 168 & 3.48 & .70 & & & & \\
\hline \multirow{4}{*}{ Performance Task } & Anatolian High School & 336 & 3.12 & .96 & & \multirow{4}{*}{11.53} & \multirow{4}{*}{.00} & $1-2$ \\
\hline & Science High School & 53 & 2.68 & 1.07 & 3 & & & $2-4$ \\
\hline & Teacher Training High School & 49 & 2.60 & .89 & 602 & & & $1-3$ \\
\hline & Vocational High School & 168 & 3.33 & .86 & 605 & & & $3-4$ \\
\hline \multirow{4}{*}{ Tablet } & Anatolian High School & 336 & 3.14 & .99 & & \multirow{4}{*}{2.52} & \multirow{4}{*}{.06} & \multirow{12}{*}{$\begin{array}{l}1-3 \\
4-3\end{array}$} \\
\hline & Science High School & 53 & 2.79 & .82 & 3 & & & \\
\hline & Teacher Training High School & 49 & 3.20 & .93 & 602 & & & \\
\hline & Vocational High School & 168 & 3.01 & .89 & & & & \\
\hline \multirow{4}{*}{ Course book } & Anatolian High School & 336 & 3.11 & .85 & & \multirow{4}{*}{4.88} & \multirow{4}{*}{.00} & \\
\hline & Science High School & 53 & 2.98 & .71 & 3 & & & \\
\hline & Teacher Training High School & 49 & 2.75 & .60 & 602 & & & \\
\hline & Vocational High School & 168 & 3.22 & .73 & 605 & & & \\
\hline \multirow{4}{*}{ Regulation Change } & Anatolian High School & 336 & 3.27 & .85 & & \multirow{4}{*}{1.69} & \multirow{4}{*}{.17} & \\
\hline & Science High School & 53 & 3.11 & .87 & 3 & & & \\
\hline & Teacher Training High School & 49 & 3.42 & .69 & 605 & & & \\
\hline & Vocational High School & 168 & 3.36 & .88 & & & & \\
\hline
\end{tabular}

One-Way ANOVA results of students' view points on innovations made in schools by Turkish National Education are given in Table 9 based on sub-variable "type of school". Accordingly, a significant difference was observed in the students' viewpoints on smart board application according to school type variable $[F(3-602)=3.11 ; p<.05]$. This difference was found more significant for the Anatolian High schools. According to the table, the viewpoints of the students in Anatolian High School and Vocational High Schools on smart board application were determined as "I agree". Science and Teacher Training High School students' viewpoints on smart board application were determined as "I am indecisive".

According to Table 9, a significant difference was observed in students' viewpoints on performance task $[F(3-602)=11.53$; $p<.05]$. This difference was found at significant level in Anatolian and Vocational High School students. In addition, the viewpoints of the Teacher Training High School students, Anatolian and Vocational High Schools were determined as "I am indecisive".

According to variance analysis results in Table 9, the viewpoints on tablet computers distribution did not differ at a significant level according to the school type variable $[F(3-602)=2.52 ; p>.05]$. It is found that the viewpoints of students 
on tablet computers distribution were determined as "I am indecisive".

It is observed in table 9 that a significant difference was determined between the viewpoints of the students on course book distribution $[F(3-602)=4.88 ; p<.05]$. This difference was found significant in Anatolian and Vocational High School students. The average of the viewpoints of the students on course book distribution was determined as "I am indecisive".

According to the results given in Table 9, no significant difference was detected between the viewpoints of the students on changes in the exam grading system regulation according to school type variable [ $F(3-602)=1.69 ; p>.05]$. The viewpoints of the students on the exam grading system regulation were determined as "I agree". The viewpoints of the students of Anatolian, Science and Vocational High Schools were determined as "I am indecisive".

Table 10. One-Way ANOVA Results of the Some School Applications in Turkish National Education Scale Sub-Dimension according to Class Populations

\begin{tabular}{|c|c|c|c|c|c|c|c|c|}
\hline Dimensions & Population of the Classes (pcs) & $\mathrm{n}$ & $x$ & $\mathrm{~S}$ & sd & $\mathrm{F}$ & $\mathrm{p}$ & Difference Tukey \\
\hline & Between 1-25 & 81 & 3.51 & .70 & 3 & & & \\
\hline \multirow{3}{*}{ Smart Board } & Between 26-30 & 289 & 3.51 & .74 & 602 & 0.684 & .51 & \\
\hline & $31+$ students & 236 & 3.44 & .75 & 605 & & & \\
\hline & Between 1-25 & 81 & 3.23 & .84 & 3 & & & \\
\hline \multirow[t]{3}{*}{ Performance } & Between 26-30 & 289 & 3.12 & .99 & 602 & 1.507 & .22 & \\
\hline & $31+$ students & 236 & 3.03 & .96 & 605 & & & \\
\hline & Between 1-25 & 81 & 3.15 & .90 & 3 & & & \\
\hline \multirow[t]{3}{*}{ Tablet } & Between 26-30 & 289 & 3.16 & .95 & 602 & 3.467 & .03 & $3-2$ \\
\hline & $31+$ students & 236 & 2.95 & .96 & 605 & & & \\
\hline & Between 1-25 & 81 & 3.30 & .74 & 3 & & & \\
\hline \multirow{3}{*}{ Course Books } & Between 26-30 & 289 & 3.10 & .87 & 602 & 3.485 & .03 & $1-3$ \\
\hline & $31+$ students & 236 & 3.03 & .71 & 605 & & & \\
\hline & Between 1-25 & 81 & 3.45 & .83 & 3 & & & \\
\hline \multirow[t]{2}{*}{ Regulation Change } & Between 26-30 & 289 & 3.34 & .84 & 602 & 3.513 & .03 & $1-3$ \\
\hline & $31+$ students & 236 & 3.19 & .84 & 605 & & & \\
\hline
\end{tabular}

According to One Way ANOVA results given in table 10, it is found that there were no significant differences in students' viewpoints on smart board use according to class size variable $[F(3-602)=.68 ; p>.05]$. In other words, class size is not a determinant variable in smart board use. In addition, the average of the students' viewpoints on smart board application based on class size was determined as "I agree".

Moreover, it is observed that no significant difference was determined on assigning students with performance tasks according to size of class variable $[F(3-602)=1.50 ; p>.05]$. Therefore, class size is found not to be a determinant variable in performance task assignments. In addition, the average viewpoints of the students on performance task assignment based on class size were determined as "I am indecisive".

One Way ANOVA results revealed that a significant difference was determined in the viewpoints of the students according to class size variable on tablet computers' distribution $[F(3-602)=3.46 ; p<.05]$. In terms of class size, this difference was found significant in classes with 26-30 students in comparison to classes with 26-30 and 31+ students. Therefore, class size was found to be a determinant variable in tablet computers distribution. In addition, students' viewpoints on tablet computers distribution were determined as "I am indecisive".

It is also observed that there was a significant difference between the viewpoints of the students on course book distribution according to class size variable $[F(3-602)=3.48 ; p<.05]$. This difference was found significant in classes with 25 and less students and classes with 31 and over students. Therefore, course books distribution is found not to be a determinant variable in class size. In addition, the viewpoints of the students on course books distribution were determined as "I am indecisive".

One Way ANOVA results given in table 10, also revealed that students' viewpoints on changes regulation on exam grading system found different at a significant level according to class size variable $[F(3-602)=1.68 ; p<.05]$. This difference was found significant in classes with 26-30 students as compared to class with 25 and less and $31+$ students. In other words, class size variable in the exam grading regulation was found to be a determinant variable. In addition, the students' viewpoints on changes in the exam grading regulation were determined as "I agree" in classes with 25 and less students; and as "I am indecisive" in the other groups.

\section{Discussion and Result}

- It is determined that the high school students' viewpoints do not differ at a significant level on smart board use, performance task, tablet computers, course book and exam grading regulation according to gender variable. 
- It is found that the high school students' viewpoints do not differ at a significant level on smart board use, performance task, tablet computers, course book and exam grading regulation according to residential area variable.

- High school students do not consider that performance task, tablet computers use, course books distribution and new exam grading regulation are useful. However, it is found that they consider use of smart board a little more beneficial. This situation may be explained with some factors like performance tasks increasing students' burdens, tablet computers are not being used actively during classes, the contents and visual images of course books are not liked much.

- A significant difference was observed in the viewpoints of the high school students on smart board use according to school type variable in Anatolian high schools. This situation may be explained with more active use of smart boards in classes in those schools. In the high schools of study area these technologies were started earlier than the other high schools.

- A significant difference was observed in the viewpoints of the high school students on performance task in Anatolian and Vocational high schools. This situation may be explained as students considering the performance tasks as a tool for increasing their grades in classes.

- A significant difference was observed in the viewpoints of the high school students on course book distribution in Anatolian and Vocational high schools. This situation may be interpreted as students' considering the course books as being more beneficial.

- No significant differences were detected between the high school students' viewpoints on tablet computers distribution and exam grading regulation changes according to the school type variable.

- No significant differences were detected between the high school students' viewpoints on assigning performance tasks according to class size variable.

- A significant difference was detected between the viewpoints of the high school students' in the classes with 26-30 students on the tablet computers distribution according to class size variable.

- A significant difference was detected between the viewpoints of the high school students' in the classes with 1-25 students on the course book distribution according to class size variable.

- A significant difference was detected between the viewpoints of the high school students' in classes with 1-25 students on the changes in exam grading regulation according to class size variable.

- In addition, the viewpoints of the high school students on smart board use, performance task, were mostly determined as "I am indecisive". Kanatlı (2008), Birgin and Gürbüz (2008), Çakan (2004), Güven and Eskitürk (2007), Özsevgeç, Çepni and Demircioğlu (2004), Yücel (2008) have found that teachers and students consider these innovations unnecessary and do not benefit from their performance. These results also correspond to the findings of the study because in the study, the views about given performance homework to students are at the level of hesitation.

- In addition, the viewpoints of the high school students on tablet computers distribution, provision of course books, changes in the exam grading regulation were mostly determined as "I am indecisive". In their works of Gümüş (2004), Kolaç (2003), Sezgin (2000), Ruhi and Kocaman (1996), Sözen (2011) on textbooks, they determined the textbook as mediocre from content, linguistic knowledge and visual angles. In the study, the views on the textbooks are at the level of hesitation and coincide the results of others studies.

- Smith (1968) emphasized that feedback of such works cannot be taken very early; The Word Economic Forum (2011) emphasized that it would be wrong to expect to learn and apply the innovations in this context in a short time; Dinçer et al. (2014) emphasized that it is wrong to start such innovations without parent and student's opinion and this view correspond to the results of the study. In addition, Yeni Palabiylk (2013), Gursul and Tozmaz (2010); Çiftçi and et al., (2013) Güven (2012), Dursun and et al. (2013), Karataş and Sözcü 2013) revealed that the infrastructure, technical inadequacies, teachers and students are not well understood yet and this is parallel to the results of the study.

\section{Recommendations}

The study results showed that the viewpoints of the high school students were determined as "I am indecisive" on use of smart boards, performance task, distribution of tablet computers, course books, changes in exam grading regulation. These kinds of innovations in high schools should be planned properly without any populist approach and must consider viewpoints of high school teachers, students and parents, who would be the practitioners of such innovations. It is also recommended that the learning and teaching processes should be planned by making use of the services of pedagogues, 
teachers, educationalists along with consideration of viewpoints of the students, who are the beneficiaries of the education-learning services.

The study results show that the viewpoints of the students change according to various variables like school type, smart board use, performance task, tablet computers distribution, course books and changes in exam grading. This situation shows that the education provided in different high school types is not the same. It is recommended that the students who are in the same age group should be provided with these innovations by considering their school types rather than providing standard applications.

\section{References}

Alkan, T., Bilici, A., Akdur, T. T., Temizhan, O., \& Çiçek, H. (2011). Increasing Opportunities Improving Technology Movement (Faith Project), 5th International Educational Technology Conference. Elazığ: Firat University.

Ayvac1, H., Ş., Bakırc1, H., \& Başak, M. H. (2014). The Evaluation Of Problems Emerging During The Implementation Process Of Faith Project By Administrators, Teachers And Students. (YYU Journal Of Education Faculty), XI(I), 21-47 http://efdergi.yyu.edu.tr

Bağc1, H. (2013). In Favour of Faith Project: Review of Students Opinions Related To The Smart Boards Okan Uni. Social Sciences Institute, Unpublished master thesis, İstanbul.

Birgin, O., \& Gürbüz. R. (2008). Preservice Elementary Teachers' Assessment Beliefs Selçuk Uni. Social Sciences Institute, 20, 163-180.

Bordanac1, Z. (2006). Russell's Educational problem in terms of communal, Atatürk Uni., Social Science Institute, Unpublished master's thesis, Erzurum.

Borg, W. R., \& Gall, M. D. (1971). Educational, Research. New York: David McKay Co. Inc., (ed. 2) (ed. 3).

Büyüköztürk, Ş. (2013). Statistics, Research Design SPSS Applications and Comment. Pegem Academy Ankara.

Çakan, M. (2004). Comparison of Elementary and Secondary School Teachers in Terms of Their Assessment Practices and Perceptions toward Their Qualification Levels. Ankara Uni. Journal of Education Faculty, 37(2), 99-114.

Çiftçi, S., Taşkaya, S. M., \& Alemdar, Ö. (2013). The Opinions of Classroom Teachers about Faith Project. Elementary Education Online, 12(1), 227-240.

Dinçer, S., Şenkal, O., \& Sezgin, M. E. (2014). Teacher, Student and Parent Coordination in Faith Project and Computer Literacy Levels, Akademik Bilişim 2013, Antalya, 23-25 Ocak 2013, 12-16.

Dursun, Ö. Ö., Kuzu, A., Kurt, A. A., Güllüpınar, F., \& Gültekin, M. (2013). Views of School Administrators' On FAITH Projects Pilot Implementation Process. Trakya University Journal of Education Faculty, 3(1), 100-113.

Ekici, S., \& Yılmaz, B. (2013). Movement to Enhance Opportunities and Improve Technology. Tukish Librarianship, 27(2), 317-339.

Faith Project, The Education of the Future" Okan University, Education of the Future's Workshop 11-12th June, (2012), İstanbul

Faith Project. "About The Project” Access date: 06. 01. 2012 Ministry of National Education Rep. of Turkey Faith Project Website: http://Faithprojesi.meb.gov.tr/tr/icerikincele.php?

Fidan, N., \& Erden, M. (1988). Introduction to Education Science. Capital Publisher. Ankara

Gümüş, E., (2004). A view to High-school Geography Books, İstanbul: Journal of Hasan Ali Yücel Education Faculty, 1, $83-87$.

Gursul, F., \& Tozmaz, G. B. (2010). Which One İs Smarter? Teacher or Board. Procedia Social and Behavioral Sciences, 2, 5731-5737.

Güven, B., \& Eskitürk, M. (2007). Measurement and Assessment Methods and Technıques of Primary School Teachers' 16. National Education Sciences Cong. Gazi Osmanpaşa University, Education Faculty, Tokat.

Güven, İ. (2012). 4+4+4 and Faith Project Bill = Is A Reform? Elementary Education Online, 11(3), 556-577. https://doi.org/10.1016/j.sbspro.2010.03.936

Harton, H. C., Richardson, D. S., Barreras, R. E., Rocloff, M. J., \& Latane, B. (2002). Focused Interactive Learning: A Tool for Active Class Discussion. Teaching of Psychology, 29(1), 10-15. https://doi.org/10.1207/S15328023TOP2901_03

Kalem-Fer (2003). The Effects of the Active Learning Model on Students' Learning, Teaching And Communication Skills. Educational Sciences: Theory and Practice. Nov. 2003, Vol. 3 Issue 2, p433-461 28p. 7 Charts. 
Kanatl1, F. (2008). The Evaluatıon of Classroom Teachers' Opinions on the Alternatıve Assessments Techniques. Unpublished Master Thesis., Mustafa Kemal Üniversitesi Social Sciences Ins., Hatay.

Karasar, N. (1994). Scientific Research Method. 6th Press, Ankara: 3A Research Education Consulting Co., Ltd.

Karataş, İ. H., \& Sözcü, Ö. F. (2013). School Administrator' Awareness and Expectations Related to the Faith Project: A Situation Analysis. Electronic Journal of Social Sciences, 12(47), 41-62.

Kolaç, E. (2003) The Evaluation of the Primary Education Fourth Grade Turkish Course Books with Regard to Teachers' Views. Uludağ Un. Education Faculty Journal of Education Faculty. XVII(1).

Küçükahmet, L. (1997). Teaching Curriculum. Ankara: Gazi Bookstore.

Küçüktepe, S., \& Baykın, E. Y. (2014). An Investigation of Teachers' Views on the Application of Faith Project in English Classes. Journal of Research in Education and Teaching, 4, Article: 23 ISSN 2146-9199.

Özsevgeç, T., Çepni, S., \& Demircioğlu, G. (2004). The Determınatıon of Prımary Educatıon Science Teachers' Literacy Level of Measurement and Assessment, 4th. National Science and Mathematic Education Cong., Marmara University, İstanbul.

Ruhi, Ş., \& Kocaman, A. (1996). A. Using Language in Primary Schools Books. Primary School' Books At Turkey And Germany. Istanbul: Turkish-German Culture Business Assembly Presses, 11, 12-24.

Sezgin, G. (2000). As Study Of The Turkish Textbooks In The 6th Grade of Primary Education. Unpublished master thesis, Gazi Uni. Social Science Institute, Ankara.

Smith, M. B. (1968). Attitude Change. International Encyclopedia of the Social Sciences. Crowell Collier and Mac Millan.

Sözen, E. (2011). Assessment Of Geography 10th Grade Geography Curriculum Teaching Program Based On Teachers' Views. Gazi Uni., Institute Of Sciences Education, Geography Science Unpublished Doctoral Thesis. Ankara.

Sözen, E., \& Türksever, Ö. (2013). Contradictions and Faults about Clima Topics in the 9th Grade and 10th Grade Geography Text Books. International Journal Social Science Research, 2(2).

World Economic Forum, (2011). Global Talent Risk - Seven Responses Geneva. World Economic Forum.

Yeni, P. P. (2013). In-service EFL Teachers 'Self-Efficacy Beliefs for Technology Integration: Insights from FATIH Project. Unpublished Master Thesis. Abant İzzet Baysal University, Bolu.

Yücel, A. (2008). Performance Homework That Are Given To Primary School 7 Years Social Knowledge Lesson (Example Of Konya). Unpublished Master Thesis., Selçuk Un. Social Sciences Institute, Konya. http://www.resmigazete.gov.tr/eskiler/2013/09/20130907-4.htm

\section{Copyrights}

Copyright for this article is retained by the author(s), with first publication rights granted to the journal.

This is an open-access article distributed under the terms and conditions of the Creative Commons Attribution license which permits unrestricted use, distribution, and reproduction in any medium, provided the original work is properly cited. 